\title{
Cultivar development and links to industry
}

\author{
R.J.M. HAY and J.A. LANCASHIRE \\ AgResearch Grasslands, Private Bag 11008, Palmerston North, New Zealand
}

\begin{abstract}
A brief history of how DSIR Grasslands operated as a plant breeding institute for New Zealand pastoral farming is presented, and this perspective shows how the present situation has been shaped whereby cultivars are now developed under contract to the forage division of AgResearch. A hypothetical cultivar development programme is detailed to show the mechanics of the Cultivar Development and Maintenance Unit (CDMU) operation. The role of CDMU in the future is discussed along with the continuing pressure for white clover seed production area in Canterbury.
\end{abstract}

Keywords: buried seed, CDMU, cultivar development, plant variety rights, seed industry

\section{History}

DSIR Grasslands was established in 1936 in response to a perceived need for New Zealand to formally research the grassland component of pastoral farming and establish professional expertise in that area. It arose from government recognition that the whole economy was based on export receipts from pastoral products.

One of its major briefs was to breed cultivars to replace the unproductive wild white clover, and nonpersistent and poorly adapted English hay type perennial ryegrasses being used in New Zealand agriculture at that time. With the willing assistance of people such as Sir George Stapleton and William Davies from the Welsh Plant Breeding Station, Sir Bruce Levy and others produced the first New Zealand cultivars which subsequently went into the newly established Seed Certification Scheme. These included Grasslands Huia white clover, Grasslands Ruanui ryegrass and Grasslands Hamua and Grasslands Turoa red clovers. These cultivars were considerable improvements on those existing in the New Zealand seeds industry at the time.

\section{Recent History}

Until restructuring three years ago, DSIR Grasslands acted as a plant breeding institute for New Zealand pastoral farming. It bred improved cultivars which were completed under government funding, given $\mathrm{G}$ numbers, and released to industry through a complicated protocol of expressions of interest which were subject to scrutiny, not only by DSIR Grasslands but by the New Zealand Grain and Seed Trade Association and the Herbage Subsection of Federated Farmers who provided some funding for breeding work in the late 1980s and early 1990s. In response to pressures from recently established private plant breeding companies, the government started, in the mid-1980s, to withdraw funding from the cultivar development end of plant improvement research. This coincided with the promulgation of protocols from Plant Variety Rights (PVR) legislation to enable legal protection, and for breeders to obtain royalty payments from sales. It was important for Grasslands to establish a royalty revenue stream to replace the continuing withdrawal of government funding in this area.

DSIR Grasslands became an avid and early user of PVR protection driven largely by the need for survival, but also from the belief that it would promote the competitive advantage New Zealand enjoys for pastoral products in the international marketplace. By the early 1990s tensions had built up between the private plant breeding sector and DSIR Grasslands, who were seen by these companies as competing directly with them in plant breeding. After considerable discussion, a Memorandum of Understanding was drawn up between New Zealand Private Breeders Research Association and DSIR Grasslands which was restructured into a Crown Research Institute and became AgResearch Grasslands.

The Memorandum of Understanding resolved that research programmes funded from the Foundation for Research, Science and Technology would not directly develop cultivars. Such funds were to be used for the generation of useful agronomic variation in pasture forages species, the characterisation of this useful variation, the establishment of heritability and linkage to other useful traits, and the establishment of new breeding techniques to accelerate the acquisition of variation. These include interspecific hybridisation, inbreeding and molecular biology techniques that allow direct gene transfer.

This decision necessitated the development of a system which allowed access by private seed companies 
to advanced breeding lines generated through government funded programmes. Further development of breeding lines through to cultivar status was to be funded by non-government revenue. Such an arrangement had to satisfy not only AgResearch Grasslands and the private seed companies, but also the government funding agency.

\section{Present Situation}

A separate unit called the Cultivar Development and Management Unit (CDMU) has been established within AgResearch Grasslands to be financially transparent and separate from government funding. Its revenue is derived through royalty flow from cultivars in commercial practice and contract funding from seed companies for specific cultivar development programmes. This system is an extremely gqod model for the commercialisation of advanced germplasm, and has certainly been looked at very hard for adoption by other countries, particularly Australia.

Another area of concern was the amount of time and effort AgResearch Grasslands was investing into establishing links with international institutes.

Some parts of the pastoral industry interpreted this development as AgResearch Grasslands "selling off" its knowledge and germplasm to countries with which New Zealand competed. However, since every single plant and animal used in agriculture, horticulture, the arable industry and most of the forestry industry were imported to New Zealand, shutting our borders to germplasm exchange and new science techniques could only increase our vulnerability. New Zealand's primary industries always have far more to gain than to lose from international exchange. AgResearch Grasslands realised since it started research in 1936 that to be successful it was very dependent upon germplasm and expertise from overseas.

To this end links and joint programmes have been established by AgResearch in all continents with relevant institutes which are major users of temperate pasture forages for animal production. These will give rise to cultivars adapted to the country of intended use and will provide export opportunities for both growers and seed exporters in New Zealand. Figure 1 summarises the links between the FRST funded white clover improvement programme and the commercial sector which leads to cultivar development. It also shows the links this programme has with international collaborators. All contracts leading to the production of cultivars both nationally and internationally are facilitated by the CDMU, and are licensed through seed companies which generates commercial opportunities for both the company and growers.

\section{Mechanics of CDMU operation}

The following illustration demonstrates the operation of the CDMU. A hypothetical company approaches AgResearch Grasslands via the CDMU to breed a hairy contrary clover cultivar which has the attributes shown in Figure 2. The breeders are consulted and the feasibility of the program assessed. In this particular instance advanced breeding lines are identified from crosses between Mediterranean and temperate accessions which show good growth rates in all seasons. We already know from our research that this particular species has good levels of condensed tannins so will not cause bloat. Also known from previous research are presence of low concentrations of a wide number of alkaloids 
which give a broad spectrum pest resistance. To produce the desired cultivar, a three-year screening programme is needed against the common pasture fungal and bacterial pathogens. After this a screening programme at Lincoln for seed yield potential will identify the final parents for this new cultivar, and pre-nucleus isolation seed produced. In all a five-year cultivar development programme.

Figure 2:

\begin{tabular}{|l|}
\hline \multicolumn{1}{|c|}{ Company request } \\
\hline Hairy contrary clover (Trifolium contrarii) to have the following \\
attributes: \\
similar growth rate in all seasons of year \\
resistant to major pests and disease \\
\hline
\end{tabular}

Costings are drawn up (Figure 3) to include staff time, overheads and operating costs. An acknowledgement of previous investment in the provision of improved germplasm for this programme is not costed but has significant implications for ownership. This cost is divided in two, half coming as a research contract on achievement of milestones from the private company, the other half from current royalty income to the CDMU.

\section{Figure 3:}

\begin{tabular}{|l|}
\hline Costing for cultivar development Hairy contrary clover \\
\hline Total cost for each of five years including: \\
$\quad$ staff time \\
$\quad$ overheads \\
\hline$\quad$ improved germplasm \\
\hline Total $\div 2$ \\
\hline
\end{tabular}

The implications of this funding structure for cultivar development are two-fold. Firstly, AgResearch's half share of the funding, and the contribution of advanced breeding lines, gives rights to ownership of the intellectual property. The seed company's half share of funding entitles it, generally, to worldwide rights to market the cultivar as head licensee with the ability to sub-licence.

\section{Future}

The operation of the CDMU has evolved over a relatively short time period and may change to meet future requirements.

The major weakness in the current funding structure of new cultivar development is the complete absence of input by organisations representing the end user. These include the large industry groups such as the Dairy Board, Meat Board and the Wool Board who are still fixed and mentally limited to funding product-driven research which does not recognise the contribution of pasture feeding. New Zealand has extremely high performance index animals which cannot express their genetic potential because of under feeding. Most vets will admit that $80 \%$ of their calls are for nutritionally derived problems. For some reason New Zealand seems to have completely forgotten the adage $20 \%$ breed, $80 \%$ feed for maximising animal production (Lancashire 1982).

\section{Pressure for white clover grower area}

AgResearch Grasslands has for some time been the subject of ill-informed criticism regarding the number of white clovers it has released over the last few years. There are nine Grasslands and one private company white clover cultivars in Seed Certification in New Zealand at present. However, there are 28 overseas cultivars in Seed Certification in New Zealand this year. AgResearch makes absolutely no apology for having 9 New Zealand white clovers in this certification system, and would ask the industry to look to themselves regarding the mushrooming importation of overseas white clovers for multiplication, at present 28 , and what this is doing to the availability of suitable land, contamination and isolation problems for white clover on the Canterbury Plains.

This pressure for uncontaminated land will result in the price per kilogram to growers increasing, or alternatively, cause companies to go offshore for seed production in an attempt to meet demand for new cultivar tonnage. Land availability is a major limiting factor in the development of the proprietary white clover seed business.

In response to these problems the industry has been putting considerable pressure on the Quality Assurance Management Committee to lower certification standards, particularly in the area of cultivar change. The five year period for cultivar change is based on solid scientific evidence from many trials in Canterbury (Clifford et al. 1996). Management techniques that produce repeatable scientific data is required to convince AgResearch any change to this protocol should be considered.

\section{Conclusion}

In conclusion, New Zealand is leading the world in white clover research and cultivar development. A robust mechanism for transferring advances established from government funded research into cultivars for the 
marketplace is operating satisfactorily. Because of increasing pressure on suitable land there is a need for serious thinking regarding its continued place as white clover producer for the world. Given considered decisions are arrived at which will benefit the whole of the New Zealand industry, the future for New Zealand led international white clover technology, with research providers in partnership with the commercial sector, is a very bright one indeed.

\section{References}

Clifford, P.T.P.; Sparks, G.A.; Woodfield, D.R. 1996. The intensifying requirements for white clover cultivar change. New Zealand Society of Agronomy Special Publication No. 11/Grassland Research and Practice Series No. 6: 19-24.

Lancashire, J.A. 1982. Presidential address - sacred cows. Proceedings of New Zealand Grassland Association 43: 5-12. 